International Journal of Current Microbiology and Applied Sciences

ISSN: 2319-7706 Volume 10 Number 02 (2021)

Journal homepage: http://www.ijcmas.com

\title{
Effect of Sowing Dates on Yield and Economics of Indian Mustard (Brassica juncea L.) Varieties under Late Sown Conditions
}

\author{
Musuka Bikshapathi*, Rajesh Singh, Ekta Singh and Punnam Chhetri
}

Department of Agronomy, Sam Higgin bottom University of Agriculture Technology and Sciences, Prayagraj-211007, Uttar Pradesh, India

*Corresponding author

\section{A B S T R A C T}

\section{Keywords}

Mustard varieties, Date of sowing, Varuna, Growth, Yield

Article Info

\section{Accepted:}

20 January 2021

Available Online:

10 February 2021
A field experiment was conducted during rabi season of 2019, at crop research farm of Department of Agronomy at Sam Higgin bottom University of Agriculture, Technology and Sciences, Prayagraj with the objective to study the effect of sowing dates onyield and economics of Indian mustard (Brassica juncea L.) varieties under late sown conditions. Experiment comprises of 9 treatments replicated thrice. With 3 different dates of sowing $5^{\text {th }}$ December, $10^{\text {th }}$ December, and $15^{\text {th }}$ December; 3 varieties i.e., Varuna, Mahyco Bold, Pioneer. Maximum grain yield (2.60 $\mathrm{t} / \mathrm{ha})$, straw yield (5.32 t/ha) was recorded with the treatment no.1 Varuna + $5^{\text {th }}$ December sowing. However, maximum gross return $\left(104 \times 10^{3} ₹ / \mathrm{ha}\right)$, net return $\left(71.62 \times 10^{3} ₹ / \mathrm{ha}\right)$, and Benefit: Cost ratio (2.2) was recorded with the treatment no. 1 Varuna $+5^{\text {th }}$ December sowing.

\section{Introduction}

Indian mustard (Brassica juncea L.) belonging to the family Cruciferaeis. One of the chief winter oilseed with a major source of high quality of edible oil (37- 49\%).Mustard is the third important oilseed crop in the world after soybean (Glycine $\max$ L.) and palm (Elaeisguineensisjacq) oil. It is grown in subtropical and tropical countries in the world. Oilseed cultivation is undertaken across the country in about 26.00 million ha, covering $72 \%$ under rain fed areas and producing around 30.00 million tons of oil seed.

Out of the nine major oilseed crops grown in India, soybean (39\%), Groundnut (26\%) and Mustard (24\%) add more than $88 \%$ of total oilseed production in the country. Indian mustard is mainly cultivated in Uttar Pradesh, Madhya Pradesh, Rajasthan, Haryana, and Gujarat. Mustard contains 17-25\% of proteins, 
$8-10 \%$ of fibers, $6-10 \%$ of moisture and $10-$ $12 \%$ of extractable substances. The oil of mustard possesses a sizable amount of erucic acid $(38-57 \%)$. But the presence of toxic glucosinolates in the mustard cake renders it unsuitable as a source of human protein and is at present as manure and as cattle feed.

In India, during 2011-2012, the rapeseed and mustard crop had production of about 6.78 million tons from an area of 5.92 mha with an average productivity of $1145 \mathrm{~kg} / \mathrm{ha}$.

However, in Uttar Pradesh it is grown in $0.64 \mathrm{mha}$ with production of 0.72 million tones. The average productivity of Uttar Pradesh is 1125 kg/ ha (Anonymous, 2012). In India, its cultivation is mainly confined in the states viz., Rajasthan, Uttar Pradesh, Madhya Pradesh, Haryana, Punjab, Assam, Bihar, Gujarat and West Bengal.

Among the states, Uttar Pradesh alone produces about 20 per cent of total mustard production in India. Indian mustard belongs to cruciferae family, genus Brassica and species juncea. Rapeseed is locally called sarson, toria, yellow toria, whereas, Mustard is called rai or laha. Though, the rapeseed and mustard belong to the same family and genus, they differ with respect to their plant characteristics.

Mustard is cultivated in mostly under temperate climates. It is also grown in certain tropical and subtropical regions as a cold weather crop. Indian mustard is reported to tolerate annual precipitation of 500 to 1200 $\mathrm{mm}$, annual temperature of 6 to $27 \mathrm{OC}$, and soil $\mathrm{pH}$ of 4.3 to 8.3 .

Rapeseed - mustard follows C-3 pathway for carbon assimilation. Therefore, it has efficient photosynthetic response at 15 to 20 0C temperature. At this temperature the plant achieve maximum $\mathrm{CO}_{2}$ exchange range which declines thereafter. Mustard requires well drained sandy loam soil. Rapeseed - mustard has a low water requirement $(240-400 \mathrm{~mm})$ which fits well in the rainfed cropping system. Nearly $20 \%$ these crops are rain-fed (Shekhawat et al., 2012).

Rapeseed and mustard are usually sown by the end of September to second fortnight of October in north India when grown as a sole crop or on dates of the main crop when sown as mixed or intercrop.

But, with the development of new varieties of crops and adoption of multiple cropping systems under irrigated condition, it has become essential to extend their sowing from October to mid of November or even later.

Singh and Singh (2002) conducted a field experiment at Faizabad (Uttar Pradesh) and recorded higher stover yield with $14^{\text {th }}$ October sowing as compared to $29^{\text {th }}$ October, $13^{\text {th }}$ November and $28^{\text {th }}$ November sowing.

Delayed sowing owing to change in biotic and abiotic environmental conditions may have adverse effect the crop performance. It necessitates developing suitable agro techniques to augment the productivity of the crop.

Among the different agronomic practices, optimum sowing time plays an important role to fully exploit the genetic potentiality of a variety as it provides optimum crop growing environment such as temperature, humidity and light etc. Sowing time is one of the most important non-monetary input which influences to a great extent on both the productivity of seed and oil (Shekhawat et al., 2012).

Awasthi et al., (2007) at Kanpur, Uttar Pradesh, to evaluate the effect of sowing dates (15 and 30 October) on growth and yield of 
two varieties of ('Vaibhav' and 'Urwashi') of Indian mustard under rainfed conditions. Sowing on 15 October achieved higher seed compared to sowing on 30 October.

Keeping in view the importance of mustard as a major oil seed crop of this state the present study was investigated to study the "Effect of sowing dates on yield and economics of different Indian mustard (Brassica juncea L.) Varieties under late sown conditions" was conducted during Rabi season 2019.

\section{Materials and Methods}

A field experiment was conducted during kharif season of 2019, at Crop research farm of Department of Agronomy at Sam Higgin bottom University of Agriculture, Technology, and Sciences, Prayagraj which is located at $25^{\circ}$ $24^{\prime} 42^{\prime \prime} \mathrm{N}$ latitude, $81^{\circ} 50^{\prime} 56^{\prime \prime} \mathrm{E}$ longitude and $98 \mathrm{~m}$ altitude above the mean sea level (MSL).

To assess the effect of sowing dates on yield and economics of various Indian mustard (Brassica juncea L.) varieties under late sown conditions.

The experiment was laid out in Randomized Block Design comprising of 9 treatments which are replicated thrice. Each treatment net plot size is $3 \mathrm{~m} \times 3 \mathrm{~m}$. Consisting of 2 factors i.e., Factor-1: Different dates of sowing; at $5^{\text {th }}$ December, $10^{\text {th }}$ December, and $15^{\text {th }}$ December and Factor-2: Different varieties of mustard i.e., Varuna, Mahycobold, pioneer; both factors were combined to form 9 treatments $\mathrm{T} 1$ : Varuna $+5^{\text {th }}$ December, T2: Mahyco bold $+5^{\text {th }}$ December, T3: Pioneer + $5^{\text {th }}$ December,T4: Varuna $+10^{\text {th }}$ December, T5: Mahycobold $+10^{\text {th }}$ December, T6: Pioneer + $10^{\text {th }}$ December, T7: Varuna $+15^{\text {th }}$ December, T8: Mahycobold $+15^{\text {th }}$ December, T9: Pioneer $+15^{\text {th }}$ December. During sowing as per the treatment combination, nitrogen fertilizer was applied at three split doses half of the nitrogen fertilizer was applied as basal dose and rest parts are divided equally and applied 45 and 60 days after sowing.

The mustard crop was harvested treatment wise at harvesting maturity stage. After harvesting, grains were separated from each net plot and were dried under sun for three days.

Later winnowed, cleaned and weight of the grain per net plot value, the grain yield per ha was computed and expressed in tonnes per hectare. After complete drying under sun for 10 days straw yield from each net plot was recorded and expressed in tones per hectare. The benefit: cost ratio was worked out after price value of grain with straw and total cost included in crop cultivation.

After thorough field preparation initial soil samples were taken to analyze for available major nutrients. Nitrogen $(\mathrm{N})$, phosphorous $(\mathrm{P})$, potassium $(\mathrm{K})$, sulphur $(\mathrm{S})$, Organic Carbon (OC), $\mathrm{pH}$ and soluble salts.

The type of soil in experimental field is sandy clay. The $\mathrm{pH}$ of the experimental field was 7.6, EC of $0.30 \mathrm{dS} / \mathrm{m}$, organic carbon was $0.47 \%$.

The $\mathrm{N}$ status of the experimental field was low (215 kg/ ha), medium in available $\mathrm{P}(13 \mathrm{~kg} /$ ha) while available $\mathrm{K}$ status was in higher range $(233 \mathrm{~kg} / \mathrm{ha})$.

The oxidizable organic carbon was determined by Walkley and Black (1934), $\mathrm{pH}$ by $\mathrm{pH}$ meter and ECe by electrical conductivity bridge with glass electrode in a 1:2.5 soil water suspension (Jackson 1973).

Available nitrogen was determined by Subbiah and Asija (1956), Available phosphorus was determined by Olsen et al., (1954) and available potash was determined by Flame photometric method, Jackson (1973). 


\section{Results and Disscusion}

\section{Effect on yield and economics}

\section{Grain yield (t/ha)}

Significant and highest grain yield (2.60 t/ha) was observed under Varuna sown during $5^{\text {th }}$ December. However, Pioneer sown during $5^{\text {th }}$ December was found to be statistically on par with Varuna sown during $5^{\text {th }}$ December.

The data reveal that date of sowing and varieties significantly influenced the seed yield of mustard. Different dates of sowing under investigation brought significant influence on the seed yield.

Seed yield was significantly affected by the dates of sowing, early sowing has gained maximum yield and also drastically affected by the delay in the sowing might be due to the high temperature at the reproductive stages of the crop Tuteja et al., (1996) and Panwar et al., (2000). Seed yield was significantly influenced due to varieties.

Among the varieties Varuna sown during $5^{\text {th }}$ December recorded significantly higher seed yield as compared to mahyco bold and at par with pioneer in the line with Jain et al., (1986) and Porwal et al., (1989) (Table 1).

\section{Straw yield (t/ha)}

Similar trend of grain yield was repeated in case of straw yield. Highest straw yield (5.32 t/ha) was observed under Varuna sown during $5^{\text {th }}$ December. However, Pioneer sown during $5^{\text {th }}$ December was found to be statistically on par with Varuna sown during $5^{\text {th }}$ December. Different dates of sowing under investigation brought significant influence on the stover yield. Stover yield has varied from variety to variety. Among the varieties, Varuna recorded significantly higher stover yield as compared to mahyco bold and at par with pioneer.

All the growth and yield attributes which determined the seed and stover yield of mustard crop, were adversely influenced when the sowing was done on too early and late sowing, which might be resulted to poor growth and translocation of photosynthates from source to sink and ultimately lower yield was recorded.

Significant reduction in seed and stover yield of mustard in too early and late sown have also been reported by Panwar et al., (2000) and Sabina et al., (2015).

\section{Effect on economics}

Maximum gross return $\left(104 \times 10^{3}\right)$, net return $\left(71.62 \times 10^{3}\right)$ and Benefit: cost ratio (2.2) was recorded with the $\mathrm{T} 1$ Varuna $+5^{\text {th }}$ December sowing.

This was due to higher seed yield and stover yield and net retains obtained with Varuna T$59+$ December $5^{\text {th }}$. Similar results were also reported by Singh et al., (2010).

It is inferred from the present investigation that environmentally and economically, Treatment no. 1 Varuna T-59 $+5^{\text {th }}$ December sowing is preferable and suitable for the farmers considering the maximum grain yield (2.60 t/ha), gross return $\left(104 \times 10^{3} \mathrm{INR} / \mathrm{ha}\right)$, net return $\left(71.62 \times 10^{3} \mathrm{INR} / \mathrm{ha}\right)$ and $\mathrm{B}: \mathrm{C}$ ratio (2.2) (Table 2). 
Table.1 Effect of sowing dates on yield of different Indian mustard (Brassica juncea L.) varieties under late sown conditions

\begin{tabular}{|c|c|c|}
\hline Treatment Combinations & Grain yield (t/ha) & Straw yield (t/ha) \\
\hline $\mathbf{T}_{\mathbf{1}}$-Varuna T-59 + December 5 & 2.60 & 5.32 \\
\hline $\mathbf{T}_{\mathbf{2}}$-Mahycobold + December 5 & 2.45 & 5.04 \\
\hline $\mathbf{T}_{\mathbf{3}}$-Pioneer 45S46 + December 5 & 2.26 & 4.66 \\
\hline $\mathbf{T}_{\mathbf{4}}$-Varuna T-59 + December 10 & 2.17 & 4.46 \\
\hline $\mathbf{T}_{\mathbf{5}}$-Mahycobold + December 10 & 2.15 & 4.41 \\
\hline $\mathbf{T}_{\mathbf{6}}$-Pioneer 45S46 + December 10 & 2.12 & 4.36 \\
\hline $\mathbf{T}_{\mathbf{7}}$-Varuna T-59 + December 15 & 2.00 & 4.09 \\
\hline $\mathbf{T}_{\mathbf{8}}$-Mahycobold + December 15 & 2.08 & 4.27 \\
\hline $\mathbf{T}_{\mathbf{9}}$-Pioneer 45S46 + December 15 & 1.90 & 3.91 \\
\hline SEm (+) & $\mathbf{0 . 0 9}$ & $\mathbf{0 . 1 9}$ \\
\hline CD $(\mathbf{P}=\mathbf{0 . 0 5})$ & $\mathbf{0 . 2 8}$ & $\mathbf{0 . 5 8}$ \\
\hline
\end{tabular}

Table.2 Effect of sowing dates on economics of different Indian mustard (Brassica juncea L.) varieties under late sown conditions

\begin{tabular}{|c|c|c|c|}
\hline Treatment Combinations & $\begin{array}{l}\text { Gross return } \\
\left.\text { (x 10 }{ }^{3} ₹ / h a\right)\end{array}$ & $\begin{array}{l}\text { Net return } \\
\left.\text { (x 10 } \mathbf{1 0}^{3} ₹ / \mathrm{ha}\right)\end{array}$ & $\begin{array}{c}\text { Benefit Cost ratio } \\
\text { (B:C Ratio) }\end{array}$ \\
\hline$T_{1}-$ Varuna $T-59+$ December 5 & 104.00 & 71.62 & 2.2 \\
\hline $\mathbf{T}_{2}$-Mahycobold + December 5 & 97.87 & 64.89 & 2.0 \\
\hline $\mathrm{T}_{3}$-Pioneer 45S46 + December 5 & 90.53 & 56.56 & 1.7 \\
\hline$T_{4}$-Varuna $T-59+$ December 10 & 86.93 & 54.56 & 1.7 \\
\hline T $_{5}$-Mahycobold + December 10 & 85.87 & 52.89 & 1.6 \\
\hline$T_{6}$-Pioneer 45S46 + December 10 & 84.83 & 50.85 & 1.5 \\
\hline$T_{7}$-Varuna $T-59+$ December 15 & 79.87 & 47.49 & 1.5 \\
\hline $\mathbf{T}_{8}$-Mahycobold + December 15 & 83.3 & 50.31 & 1.5 \\
\hline$T_{9}$-Pioneer 45S46 + December 15 & 76.13 & 42.15 & 1.2 \\
\hline $\operatorname{SEm}( \pm)$ & 3.20 & 3.20 & 0.07 \\
\hline $\mathrm{CD}(\mathrm{P}=\mathbf{0 . 0 5})$ & 9.38 & 9.38 & 0.21 \\
\hline
\end{tabular}

\section{References}

Anonymous, (2012). Director's report presented at the $19^{\text {th }}$ annual group meeting of rapeseed-mustard research workers held at ICAR, New Delhi, and 10 Jan. 2012.

Awasthi, U. D., Singh, R. B. and Dubey, S. D., (2007). Effect of sowing date and moisture conservation practice on growth and yield of Indian mustard
(Brassica juncea L.) varieties. Indian Journal of Agronomy, 52(3): 151-153

Jain, V.K., Chauhan, Y.S., Khandekar, M.P., Jain, D.C., Rathore, D.R. and Rathore, R.N. (1986). Performance of raya varieties under late sown conditions. Indian J. Agron., 31(4): 374-376.

Jackson, M.L. (1973). Soil Chemical Analysis. Prentice Hall of India Pvt. Ltd., New Delhi. pp. 56.

Olsen, S.H., Cole, V.V., Watanabe, F.S. and 
Dean, L.A., (1954). Estimation of available phosphorus in soil by extraction with sodium bicarbonate. United States Department of Agriculture, Circular, 939: 1-9.

Panwar, K. S., Sharma, S.K. and Nanwal, R.K., (2000). Influence of sowing times on the yield of different mustard cultivars (Brassica spp.) under conserved soil moisture conditions. Indian J. Agric. Sci., 70(6): (398-399).

Porwal, B.L., Mathur, Y.K., Gosami, S.P. and Maliwal, P.L., (1989). Biotechnical changes associated with chemical cryorotection in mustard cultivars (Brassica juncea L.). Indian J. Agron. 34(3): 293-296.

Sabina Akhter, Lal singh, RubiaRasool and ShaziaRamzan, (2015). Effect of date of sowing and varieties on yield of Brown sarson (Brassica rapa L.). under Temperate Kashmir. International journal of Engineering science, Inversion volume 4(3).65-69.

Shekhawat, Kapila, Rathore, S. S., Premi, O. P. Kandpal, B. K. and Chauhan J.S., (2012). Advances in Agronomic Management of Indian Mustard (Brassica juncea L.) Czernj.Cosson): An Overview. International Journal of Agronomy, doi:10.1155/2012/408284.

Singh, S. K. and Singh, G., (2002). Response of Indian mustard (Brassica juncea L.) varieties nitrogen under varying sowing dates in eastern Uttar Pradesh. Indian Journal of Agronomy, 47(2): 242-248

Singh, R.S., Singh, Y., Singh, A.K., Kumar, R. and Singh, V.K., (2010). Productivity and economics of mustard (Brassica juncea L.) varieties as influenced by different fertility levels under late sown condition. Ind. J. Soil Cons., 38(2): 121-124, 2010.

Subbiah B and Asija G L. (1956). A rapid procedure for estimation of available nitrogen in soils. Curr Sci. 25(8): 1-6.

Tuteja, S.S., Lakpale R and R. S. Tripathi, (1996). Effect of date of sowing, nitrogen levels and nitrogen splitting on mustard (Brassica juncea). Adv. Plant., 9(1): (167-168).

Walkley, A. and Black, I. A., (1934). An examination of degtjareff method for determining soil organic matter and a proposed modification of chromic acid titration method.Soil Sci 37: 29-37.

Panwar, K. S., S. K. Sharma and R. K. Nanwal, (2000). Influence of sowing times on the yield of different mustard cultivars (Brassica spp.) under conserved soil moisture conditions. Indian J. Agric. Sci., 70(6): (398-399).

\section{How to cite this article:}

Musuka Bikshapathi, Rajesh Singh, Ekta Singh and Punnam Chhetri. 2021. Effect of Sowing Dates on Yield and Economics of Indian Mustard (Brassica juncea L.) Varieties under Late Sown Conditions. Int.J.Curr.Microbiol.App.Sci. 10(02): 2711-2716. doi: https://doi.org/10.20546/ijcmas.2021.1002.299 